Proc. Estonian Acad. Sci. Eng., 2002, 8, 3, 174-188

\title{
Unstiffened thin-walled girder under uniform loading
}

\author{
Priit Vilba $^{\mathrm{a}}$ and Siim Idnurm ${ }^{\mathrm{b}}$ \\ a City Government, Vabaduse väljak 7, 15199 Tallinn, Estonia; pvilba@neti.ee \\ b Department of Civil Engineering, Tallinn Technical University, Ehitajate tee 5, 19086 Tallinn, \\ Estonia; sidnurm@edu.ttu.ee
}

Received 11 March 2002, in revised form 26 June 2002

\begin{abstract}
The paper focuses on the stresses and deformations of welded plate girders subjected to uniformly distributed edge loading. The critical load parameters of the web plate under the action of edge loading, shear, bending, and compressive stresses are determined. The horizontal edges of the web plate are considered to be elastically restrained, with vertical edges simply supported. The post-buckling behaviour of this web plate is analysed. In the post-buckling situation, the parts of the web plate are assumed to be simply supported and the edge load balanced by shear stresses on the adjacent edges. Numerical results of the continuous analytical and the finite element method are compared with results obtained from the Eurocode 3 formulas and with the test results.
\end{abstract}

Key words: plate girder, buckling load, post-buckling behaviour, ultimate load, Eurocode.

\section{INTRODUCTION}

In steel girder design, as a rule, shear strength and local stability of the web are ensured. However, the local stability condition of the web is not necessary, since the loss of stability does not result in the loss of the carrying capacity of the girder. The theory of the behaviour of plate girders in shear and bending and the ultimate load design of steel plate girders is described in $\left[{ }^{1-3}\right]$. The mathematical treatment of the interaction between the initial distortions and in-plane loading is described in $\left[{ }^{4}\right]$. The results obtained from hundreds of tests on girders varying in cross-sectional dimensions and in materials are described in $\left[{ }^{5-10}\right]$. These results open up the possibility to verify the values of the calculated ultimate loads. However, the test results are not entirely comparable because of different definitions of the ultimate load. Practical design methods and formulas for thin plate I-girders were elaborated by Höglund $\left[{ }^{5,6,9,10}\right]$. The behaviour of the webs of plate and box girders, subjected to repeated buckling, is described in $\left[^{11,12}\right]$. 
The carrying capacity of a slender plate girder in the post-critical stage depends on the slenderness parameters of the web and flange stiffness characteristics (compressive, torsional, and flexural rigidity). In this paper a calculation model is developed for girders without transverse and longitudinal stiffeners. The initial imperfections of the girder web are not taken into account, as they have no practical effect on the value of the ultimate load for slender plate girders.

\section{STRESSES AND DISPLACEMENTS BEFORE BUCKLING}

Let us consider a slender plate girder under uniform edge loading. When the I-girder is loaded to the point of loosing local stability, the web of the girder will buckle, forming several half-waves in the longitudinal direction (Fig. 1). The web area with the length of one or several half-waves can be considered as a separate plate (panel) for the theoretical study.

The main assumptions for an analytical study based on the plate theory $\left[{ }^{13}\right]$ are:

1) the girder is laterally restrained, i.e. no lateral-torsional buckling occurs,

2) the girder flanges have certain rigidity and are elastically connected to the web,

3) the relative elongation of flanges $\left(\varepsilon_{y}^{f}\right)$ and the web $\left(\varepsilon_{y}^{w}\right)$ are equal:

$$
\varepsilon_{y}^{w}=\varepsilon_{y}^{f}, \quad(x=0, h) .
$$
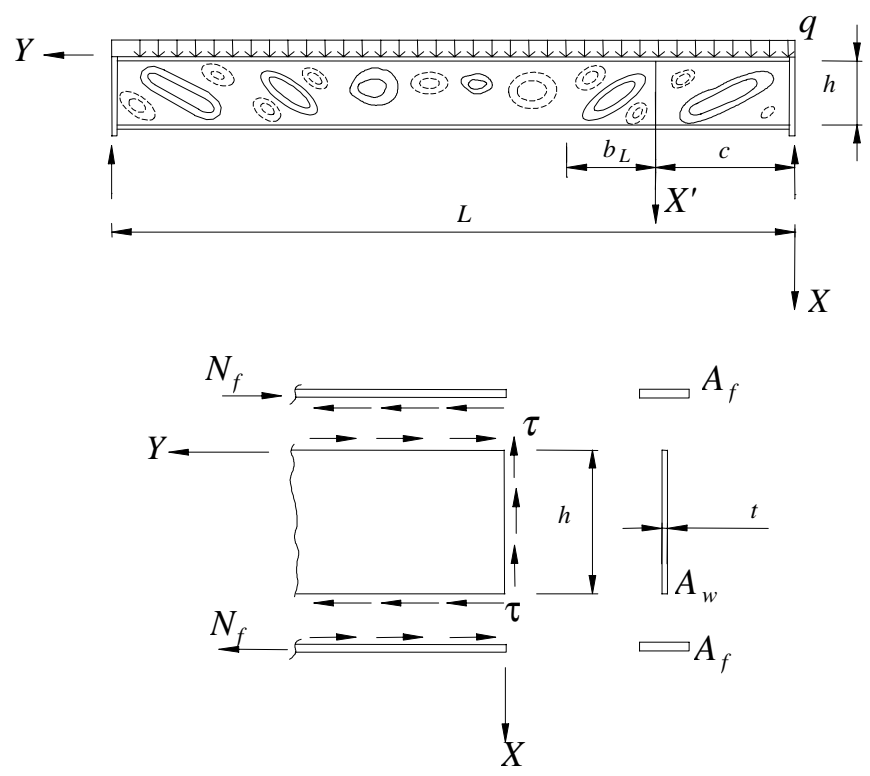

Fig. 1. Analytical model and stresses between the web and flanges. 
The uniformly distributed load $q$ can be expanded into the Fourier series as

$$
q=\sum_{p=1,3, \ldots} q_{p} \sin \frac{p \pi y}{L}=q_{1} \sin \frac{\pi y}{L}+q_{3} \sin \frac{3 \pi y}{L}+q_{5} \sin \frac{5 \pi y}{L}+\ldots
$$

where

$$
q_{1}=\frac{4}{\pi} q, \quad q_{3}=\frac{4}{3 \pi} q, \quad q_{5}=\frac{4}{5 \pi} q .
$$

Using the equations of equilibrium $\left[{ }^{13}\right]$

$$
\begin{aligned}
& \frac{\partial \sigma_{x}}{\partial x}+\frac{\partial \tau_{x y}}{\partial y}=0, \\
& \frac{\partial \sigma_{y}}{\partial y}+\frac{\partial \tau_{x y}}{\partial x}=0,
\end{aligned}
$$

the stress components of the girder web before buckling can be written as

$$
\begin{aligned}
\sigma_{1 x}= & \frac{E \pi}{1+\mu} \sum_{p=1, \ldots} p \sin a y\left[A_{p}^{\prime} \operatorname{ch} a x+B_{p}^{\prime}{ }_{p} \operatorname{sh} a x+\left(\frac{x}{L} \operatorname{ch} a x-\frac{1}{p \pi} \frac{1-\mu}{1+\mu} \operatorname{sh} a x\right) C_{p}\right. \\
& \left.+\left(\frac{x}{L} \operatorname{sh} a x-\frac{1}{p \pi} \frac{1-\mu}{1+\mu} \operatorname{ch} a x\right) D_{p}\right], \\
\sigma_{1 y}= & \frac{-E \pi}{1+\mu} \sum_{p=1, \ldots} p \sin a y\left[A^{\prime}{ }_{p} \operatorname{ch} a x+B^{\prime}{ }_{p} \operatorname{sh} a x+\left(\frac{x}{L} \operatorname{ch} a x-\frac{1}{p \pi} \frac{1+3 \mu}{1+\mu} \operatorname{sh} a x\right) C_{p}\right. \\
& \left.+\left(\frac{x}{L} \operatorname{sh} a x+\frac{1}{p \pi} \frac{1+3 \mu}{1+\mu} \operatorname{ch} a x\right) D_{p}\right], \\
\tau_{1 x y}= & \frac{E \pi}{1+\mu} \sum_{p=1, \ldots} p \cos a y\left[A_{p}^{\prime}{ }_{p} \operatorname{sh} a x+B^{\prime}{ }_{p} \operatorname{ch} a x+\left(\frac{x}{L} \operatorname{sh} a x-\frac{1}{p \pi} \frac{2 \mu}{1+\mu} \operatorname{ch} a x\right) C_{p}\right. \\
& \left.+\left(\frac{x}{L} \operatorname{ch} a x+\frac{1}{p \pi} \frac{2 \mu}{1+\mu} \operatorname{sh} a x\right) D_{p}\right],
\end{aligned}
$$

where $A_{p}^{\prime}=A_{p} / L, B_{p}^{\prime}=B_{p} / L, a=p \pi / L, \mu$ is the Poisson ratio and $E$ is the modulus of elasticity.

The unknown coefficients $A_{p}, B_{p}, C_{p}$, and $D_{p}$ are determined from the boundary conditions: 
1) $\sigma_{1 x}=-\frac{q}{t}, \quad(x=0)$

$$
A_{p}^{\prime}-\frac{1-\mu}{(1+\mu) p \pi} D_{p}=-\frac{q_{p}}{t E} \frac{1+\mu}{p \pi},
$$

2) $\sigma_{1 x}=0,(x=h)$

$$
\begin{gathered}
A_{p}^{\prime} \operatorname{ch} a h+B^{\prime}{ }_{p} \operatorname{sh} a h+\left(\frac{h}{L} \operatorname{ch} a h-\frac{1}{p \pi} \frac{1-\mu}{1+\mu} \operatorname{sh} a h\right) C_{p} \\
+\left(\frac{h}{L} \operatorname{sh} a h-\frac{1}{p \pi} \frac{1-\mu}{1+\mu} \operatorname{ch} a h\right) D_{p}=0 .
\end{gathered}
$$

3) $\varepsilon_{y}^{w}=\varepsilon_{y}^{f},(x=0)$

$$
A_{p}^{\prime}-K_{p}\left(B_{p}^{\prime}+\frac{2 \mu}{1+\mu} \frac{1}{p \pi} C_{p}\right)+\frac{1}{p \pi} D_{p}=0 .
$$

4) $\varepsilon_{y}^{w}=\varepsilon_{y}^{f},(x=h)$

$$
\begin{aligned}
& A_{p}^{\prime}\left(\operatorname{ch} a h+K_{p} \operatorname{sh} a h\right) B_{p}^{\prime}\left(\operatorname{sh} a x+K_{p} \operatorname{ch} a h\right) \\
& +C_{p}\left[\frac{h}{L} \operatorname{ch} a h+\frac{1}{p \pi} \operatorname{sh} a h+\left(\frac{h}{L} \operatorname{sh} a h+\frac{1}{p \pi} \frac{2 \mu}{1+\mu} \operatorname{ch} a h\right) K_{p}\right] \\
& +D_{p}\left[\frac{h}{L} \operatorname{sh} a h+\frac{1}{p \pi} \operatorname{ch} a h+\left(\frac{h}{L} \operatorname{ch} a h+\frac{1}{p \pi} \frac{2 \mu}{1+\mu} \operatorname{sh} a h\right) K_{p}\right]=0,
\end{aligned}
$$

where

$$
K_{p}=\frac{\beta}{\alpha_{1}(1+\mu) p \pi}, \quad \alpha_{1}=\frac{A_{f}}{A_{w}}, \quad \beta=\frac{L}{h} .
$$

The stress components of the separate plate $b_{L} \times h$ of the girder web before buckling can be written as

$$
\begin{aligned}
\sigma_{1 x}= & \frac{E \pi}{1+\mu} \sum_{p=1, \ldots} p\left(\cos \frac{p \pi c}{L} \sin a y+\sin \frac{p \pi c}{L} \cos a y\right)\left[A^{\prime}{ }_{p} \operatorname{ch} a x+B^{\prime}{ }_{p} \operatorname{sh} a x\right. \\
& \left.+\left(\frac{x}{L} \operatorname{ch} a x-\frac{1}{p \pi} \frac{1-\mu}{1+\mu} \operatorname{sh} a x\right) C_{p}+\left(\frac{x}{L} \operatorname{sh} a x-\frac{1}{p \pi} \frac{1-\mu}{1+\mu} \operatorname{ch} a x\right) D_{p}\right],
\end{aligned}
$$




$$
\begin{aligned}
\sigma_{1 y}= & \frac{-E \pi}{1+\mu} \sum_{p=1, \ldots} p\left(\cos \frac{p \pi c}{L} \sin a y+\sin \frac{p \pi c}{L} \cos a y\right)\left[A_{p}^{\prime} \operatorname{ch} a x+B^{\prime}{ }_{p} \operatorname{sh} a x\right. \\
& \left.+\left(\frac{x}{L} \operatorname{ch} a x+\frac{1}{p \pi} \frac{1+3 \mu}{1+\mu} \operatorname{sh} a x\right) C_{p}+\left(\frac{x}{L} \operatorname{sh} a x+\frac{1}{p \pi} \frac{1+3 \mu}{1+\mu} \operatorname{ch} a x\right) D_{p}\right], \\
\tau_{1 x y}= & \frac{E \pi}{1+\mu} \sum_{p=1, \ldots} p\left(\cos \frac{p \pi c}{L} \cos a y-\sin \frac{p \pi c}{L} \sin a y\right)\left[A^{\prime}{ }_{p} \operatorname{sh} a x+B^{\prime}{ }_{p} \operatorname{ch} a x\right. \\
& \left.+\left(\frac{x}{L} \operatorname{sh} a x+\frac{1}{p \pi} \frac{2 \mu}{1+\mu} \operatorname{ch} a x\right) C_{p}+\left(\frac{x}{L} \operatorname{ch} a x+\frac{1}{p \pi} \frac{2 \mu}{1+\mu} \operatorname{sh} a x\right) D_{p}\right]
\end{aligned}
$$

where $0 \leq x \leq h, 0 \leq y \leq b_{L}$.

\section{POST-BUCKLING STATE}

Let us consider the panel $b_{L} \times h$ (Fig. 1) loaded by stresses according to Eqs. (12)-(14). In the post-buckling state, in terms of displacements the membrane stresses are $\left[{ }^{13}\right]$

$$
\begin{gathered}
\sigma_{x}=\frac{E}{1-\mu^{2}}\left[\frac{\partial u}{\partial x}+\mu \frac{\partial v}{\partial y}+\frac{1}{2}\left(\frac{\partial w}{\partial x}\right)^{2}+\frac{\mu}{2}\left(\frac{\partial w}{\partial y}\right)^{2}\right], \\
\sigma_{y}=\frac{E}{1-\mu^{2}}\left[\frac{\partial v}{\partial y}+\frac{\partial u}{\partial x}+\frac{1}{2}\left(\frac{\partial w}{\partial y}\right)^{2}+\frac{\mu}{2}\left(\frac{\partial w}{\partial x}\right)^{2}\right] \\
\tau_{x y}=\frac{E(1-\mu)}{2\left(1-\mu^{2}\right)}\left[\frac{\partial u}{\partial y}+\frac{\partial v}{\partial x}+\frac{\partial w}{\partial x} \frac{\partial w}{\partial y}\right]
\end{gathered}
$$

and the strain-displacement equations

$$
\begin{gathered}
\varepsilon_{x}=\frac{\partial u}{\partial x}+\frac{1}{2}\left(\frac{\partial w}{\partial x}\right)^{2} \\
\varepsilon_{y}=\frac{\partial v}{\partial y}+\frac{1}{2}\left(\frac{\partial w}{\partial y}\right)^{2} \\
\gamma_{x y}=\frac{\partial u}{\partial y}+\frac{\partial u}{\partial x}
\end{gathered}
$$


Using the equations of equilibrium (3), (4) and relationships (12)-(20), the membrane stresses in the post-buckling state may be written as

$$
\begin{aligned}
\sigma_{x}=\sigma_{1 x} & +\frac{E t^{2} \pi^{2}}{h^{2}} \sum_{k} \sum_{l} R_{k l} \cos \frac{k \pi x}{h} \cos \frac{l \pi y}{b_{L}}+\frac{E \pi}{1+\mu}\left\{-\sum_{p} \cos \alpha^{\prime} y\left[E_{p} \operatorname{ch} \alpha^{\prime} x+F_{p} \operatorname{sh} \alpha^{\prime} x\right.\right. \\
& \left.\left.+G_{p}\left(\frac{x}{b_{L}} \operatorname{ch} \alpha^{\prime} x-\frac{\mu_{1}}{\mu_{2}} \frac{1}{p \pi} \operatorname{sh} \alpha^{\prime} x\right)+H_{p}\left(\frac{x}{b_{L}} \operatorname{sh} \alpha^{\prime} x-\frac{\mu_{1}}{\mu_{2}} \frac{1}{p \pi} \operatorname{ch} \alpha^{\prime} x\right)\right]\right\} \\
& +\frac{E}{1-\mu^{2}}\left(C_{10}+\mu C_{20}\right),
\end{aligned}
$$

$$
\begin{aligned}
\sigma_{y}=\sigma_{1 y} & +\frac{E t^{2} \pi^{2}}{h^{2}} \sum_{k} \sum_{l} S_{k l} \cos \frac{k \pi x}{h} \cos \frac{l \pi y}{b_{L}}+\frac{E \pi}{1+\mu}\left\{-\sum_{p} \cos \alpha^{\prime} y\left[E_{p} \operatorname{ch} \alpha^{\prime} x+F_{p} \operatorname{sh} \alpha^{\prime} x\right.\right. \\
& \left.\left.+G_{p}\left(\frac{x}{b_{L}} \operatorname{ch} \alpha^{\prime} x+\frac{\mu+\mu_{2}}{\mu_{2}} \frac{1}{p \pi} \operatorname{sh} \alpha^{\prime} x\right)+H_{p}\left(\frac{x}{b_{L}} \operatorname{sh} \alpha^{\prime} x+\frac{\mu+\mu_{2}}{\mu_{2}} \frac{1}{p \pi} \operatorname{ch} \alpha^{\prime} x\right)\right]\right\} \\
& +\frac{E}{1-\mu^{2}}\left(C_{20}+\mu C_{10}\right),
\end{aligned}
$$

$$
\begin{aligned}
& \tau_{y x}=\tau_{1 x y}+\frac{E t^{2} \pi^{2}}{h^{2}} \sum_{k} \sum_{l} T_{k l} \sin \frac{k \pi x}{h} \sin \frac{l \pi y}{b_{L}}+\frac{E \pi}{1+\mu}\left\{\sum _ { p } \operatorname { s i n } \alpha ^ { \prime } y \left[E_{p} \operatorname{sh} \alpha^{\prime} x+F_{p} \operatorname{ch} \alpha^{\prime} x\right.\right. \\
&\left.\left.+G_{p}\left(\frac{x}{b_{L}} \operatorname{sh} \alpha^{\prime} x+\frac{\mu}{\mu_{2}} \frac{1}{p \pi} \operatorname{ch} \alpha^{\prime} x\right)+H_{p}\left(\frac{x}{b_{L}} \operatorname{ch} \alpha^{\prime} x+\frac{\mu}{\mu_{2}} \frac{1}{p \pi} \operatorname{sh} \alpha^{\prime} x\right)\right]\right\},
\end{aligned}
$$

where

$$
\alpha^{\prime}=\frac{p \pi}{b_{L}}, \mu_{1}=\frac{1-\mu}{2}, \mu_{2}=\frac{1+\mu}{2} .
$$

Relative elongations of the flange and the girder web are equal. The girder flanges possess flexural rigidity and cannot buckle. The longitudinal edges of the plate will remain rectilinear and can move freely (Fig.2). Thus the unknown coefficients $E_{p}, F_{p}, G_{p}, H_{p}, C_{10}$, and $C_{20}$ can be found from the boundary conditions

$$
\frac{\partial^{2} w}{\partial x^{2}}=0, \varepsilon_{y}^{f}=\varepsilon_{y}^{w},(x=0, h)
$$



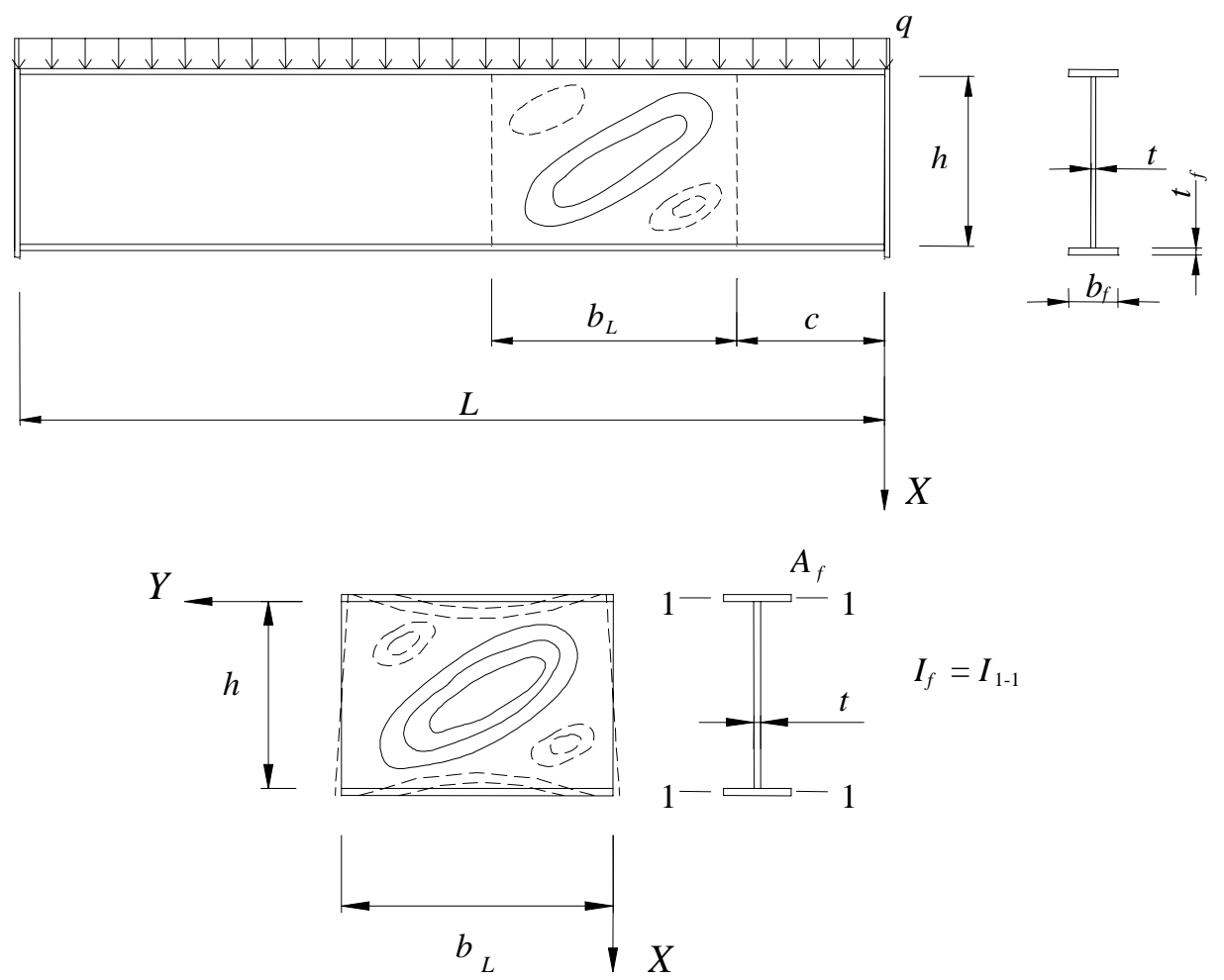

Fig. 2. A buckled panel of the girder web.

$$
\begin{gathered}
E I_{f} \frac{\partial^{4} u}{\partial y^{4}}= \pm \sigma_{x}, \\
\frac{\partial^{2} w}{\partial y^{2}}=0, \frac{\partial^{2} v}{\partial x^{2}}=0 . \quad\left(y=0 ; b_{L}\right)
\end{gathered}
$$

Substituting the plate deflection function

$$
w=t \sum_{m} \sum_{n} w_{m n} \sin \frac{m \pi x}{h} \sin \frac{n \pi y}{b_{L}}
$$

and stress expressions (21)-(23) into the differential equation of equilibrium of the plate for in-plane loading $\left[{ }^{13}\right]$

$$
\frac{D}{t} \nabla^{2} \nabla^{2} w=\sigma_{x} \frac{\partial^{2} w}{\partial x^{2}}+\sigma_{y} \frac{\partial^{2} w}{\partial y^{2}}+2 \tau_{x y} \frac{\partial^{2} w}{\partial x \partial y},
$$

where 


$$
D=\frac{E t^{3}}{12\left(1-\mu^{2}\right)},
$$

we obtain a system of non-linear algebraic equations for the calculation of the parameters $w_{m n}$ by the Bubnov-Galjorkin method $\left[{ }^{14}\right]$. This system consists of three parts: the linear, quadratic, and cubic part. The solution of this system gives the parameters $w_{m n}$ and thus the stresses in the plate can be calculated. The ultimate load is determined by the limit stress criterion proposed by von Mises $\left[{ }^{4}\right]$

$$
\sigma_{e}(q)=\sqrt{\sigma_{x}^{2}+\sigma_{y}^{2}-\sigma_{x} \sigma_{y}+3 \tau_{x y}^{2}} \leq f_{y},
$$

where the stresses include the bending and membrane components and $f_{y}$ is the yield stress. The load $q$ which corresponds to the criterion (29) is considered to be the ultimate load.

\section{THEORETICAL BUCKLING LOAD}

In order to study the influence of the torsional rigidity of the flange on the critical buckling load of the girder web, the following plate deflection function was used:

$$
w=t \sum_{m} \sum_{n} w_{m n} \sin \frac{n \pi y}{L}\left[\sin \frac{m \pi x}{h}+f_{m n}(x)\right]
$$

where

$$
f_{m n}(x)=C_{m n} \operatorname{ch} \frac{m \pi x}{h}+D_{m n} \operatorname{sh} \frac{m \pi x}{h}+E_{m n} \frac{x}{h} \operatorname{ch} \frac{m \pi x}{h}+F_{m n} \frac{x}{h} \operatorname{sh} \frac{m \pi x}{h} .
$$

The unknown coefficients $C_{m n}, D_{m n}, E_{m n}$, and $F_{m n}$ are determined from boundary conditions

$$
\begin{gathered}
w=0, \frac{\partial^{2} w}{\partial x^{2}}=\mp T \frac{\partial^{3} w}{\partial y^{2} \partial x}, \quad(x=0, h) \\
w=0, \frac{\partial^{2} w}{\partial y^{2}}=0, \quad(y=0, L)
\end{gathered}
$$

where $T$ is torsional rigidity of the flange

$$
T=\frac{G I_{c}}{D h}=2(1-\mu) \frac{b_{f}}{h}\left(\frac{t_{f}}{t}\right)^{3} .
$$

Here $I_{c}$ is the inertia moment of the flange about the local axis c (Fig. 3). 


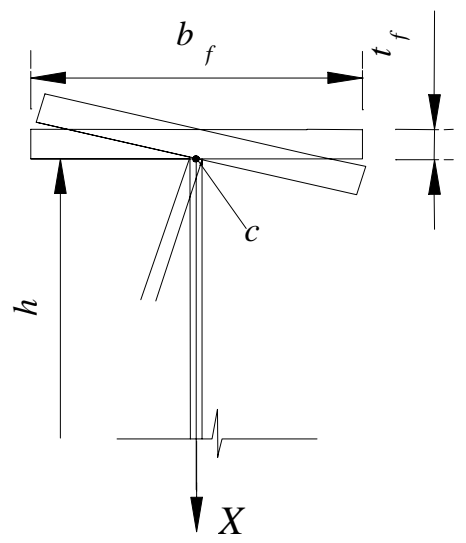

Fig. 3. Torsion of the flange.

The buckling load parameter $K$ is a function of the girder slenderness ratio $L / h$ and of the torsional parameter $T$ of the flange

$$
K(T, L / h)=\frac{q_{c r} h^{2} 12(1-\mu)^{2}}{E t^{3} \pi^{2}} .
$$

It can be determined from the linear part of the non-linear algebraic system for parameters $w_{m n}$, and the critical load for the whole girder can be calculated from Eq. (35).

\section{FINITE ELEMENT ANALYSIS}

In parallel with the calculations with the continuous analytical method based on the plate theory, finite element models were used to determine the buckling and the ultimate load (according to Eq. (29)). The numerical results were obtained using the COSMOS/M non-linear finite element analysis $\left[{ }^{15}\right]$. One half of the finite element model and the first buckling mode are shown in Fig. 4.

The results of the analytical and FEM calculations are presented in Fig. 5. It can be seen that the value of the torsional rigidity $T$ of the flange influences significantly the critical uniform buckling load $q$.

\section{EXPERIMENTAL INVESTIGATION}

The aim of the experiments was to determine the ultimate strength of the girders and to compare it with the results obtained with theoretical analysis (continuous and discrete models) and the Eurocode 3 formulas $\left[{ }^{16}\right]$.

The testing schema is shown in Fig. 6. 


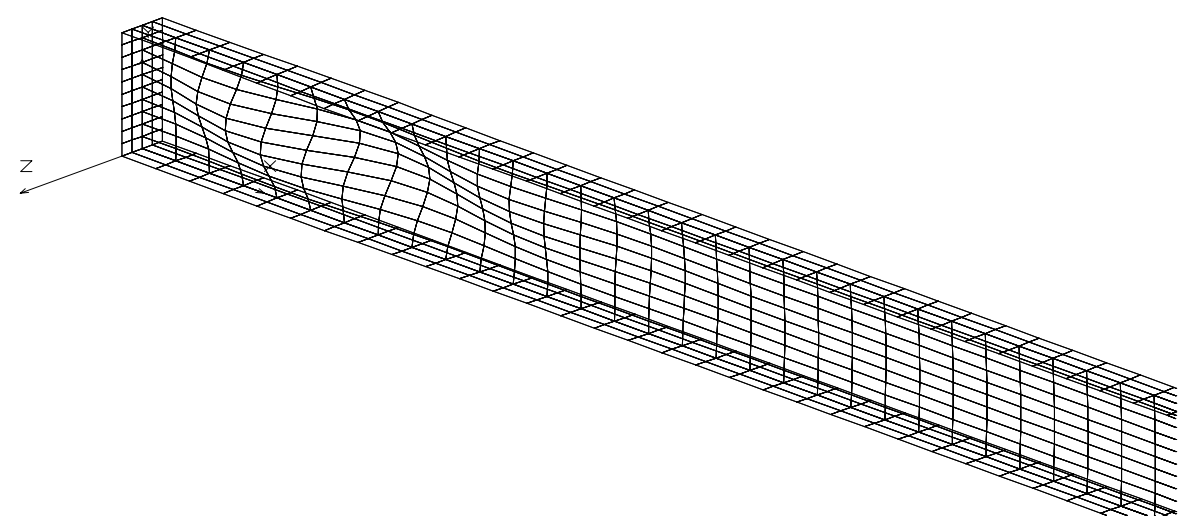

Fig. 4. FEM grid and deformed shape of the web after buckling.

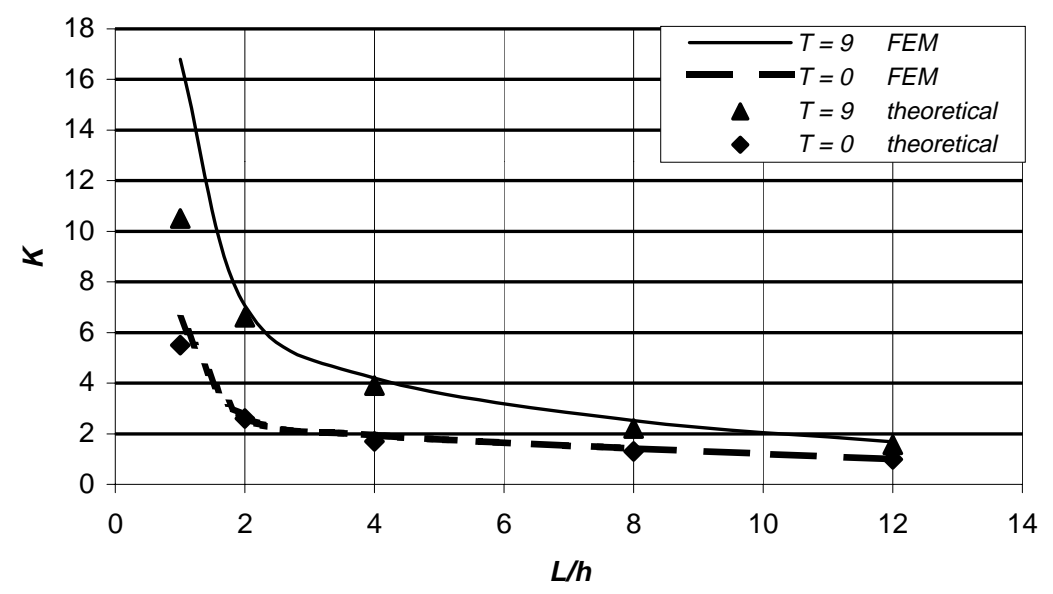

Fig. 5. Dependence of the buckling load parameter $K$ on $L / h$.

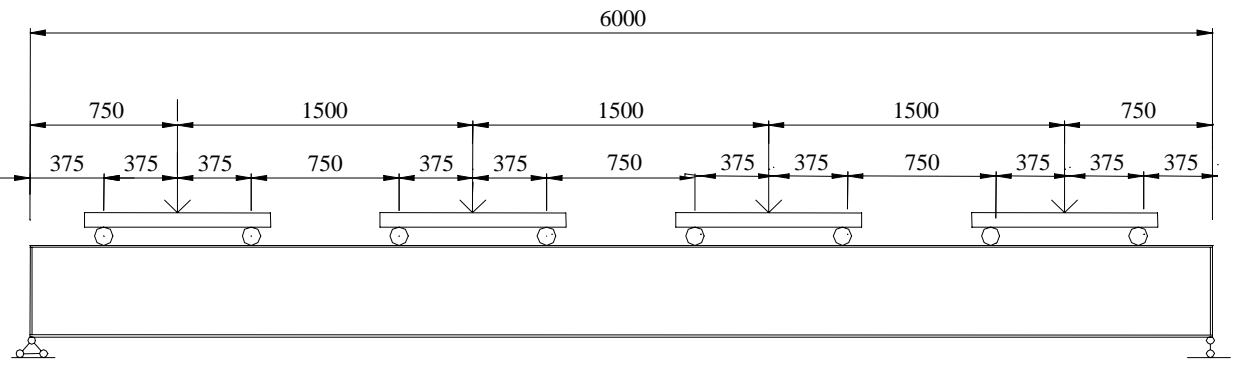

Fig. 6. Schema of the girder test. 
Special lateral supports provided stability to the compressed flange in the horizontal plane. The distance between the supports was $2.0 \mathrm{~m}$. The webs of all the test girders had considerable initial imperfections. Thus it was difficult to determine the exact critical buckling load experimentally. The ultimate load in these tests was determined by the pressure drop in the loading jack hydraulic system.

Eight girders were tested. The geometrical characteristics of the tested girders are shown in Table 1.

Girders $T_{1}$ and $T_{4}$ were provided with additional stiffeners at the ends.

Two forms of failure were observed: 1) buckling of the compressed flange in the middle of the span, 2) formation of a prolonged diagonal fold in the web close to one of the girder supports; the length of this fold was approximately 4 to 5 times the web height (typical shear failure mode). In this case, the ultimate load was determined by the web's shear buckling. The first form of collapse was observed on girders $T_{1}$ and $T_{5}$, the second form on girders $T_{2}$ to $T_{4}$ and $T_{6}$ to $T_{8}$.

The ultimate loads of the girders $T_{1}$ and $T_{4}$ (which had the rigid end stiffeners) were 20 to $30 \%$ higher than ultimate loads of the girders $T_{3}, T_{4}$ without rigid end stiffeners.

Table 1. Geometrical characteristics of the tested girders

\begin{tabular}{|c|c|c|c|c|c|c|c|c|}
\hline $\begin{array}{l}\dot{0} \\
\dot{z} \\
\dot{0} \\
\dot{0} \\
\dot{0}\end{array}$ & 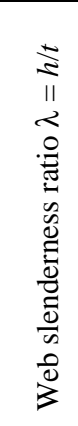 & 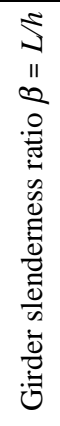 & 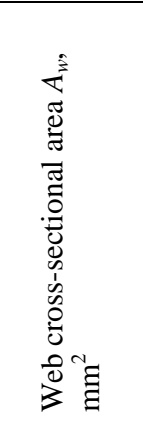 & 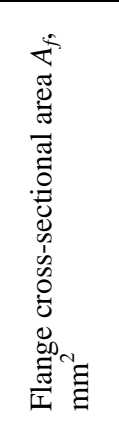 & 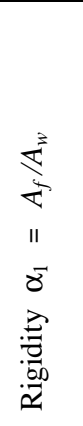 & 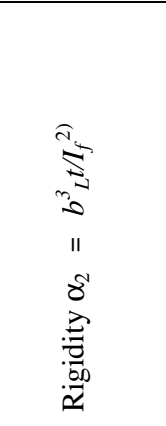 & 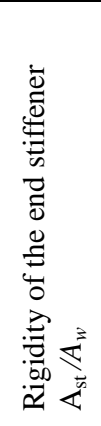 & 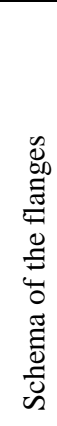 \\
\hline$T_{1}$ & 250 & 12 & $500 \times 2$ & $120 \times 6$ & 0.72 & $>200000$ & 0.72 & \\
\hline$T_{2}$ & 250 & 12 & $500 \times 2$ & $960^{1)}$ & 0.96 & $\sim 9000$ & 0.55 & \\
\hline$T_{3}$ & 333 & 12 & $500 \times 1.5$ & $960^{1)}$ & 1.28 & $\sim 7000$ & 0.73 & \\
\hline$T_{4}$ & 250 & 12 & $500 \times 2$ & $120 \times 6$ & 0.72 & $>200000$ & 0.72 & \\
\hline$T_{5}$ & 250 & 12 & $500 \times 2$ & $120 \times 6$ & 0.72 & $>200000^{2)}$ & 1.2 & \\
\hline$T_{6}$ & 250 & 12 & $500 \times 2$ & $120 \times 6$ & 0.72 & $\sim 200000^{3)}$ & 1.2 & \\
\hline$T_{7}$ & 270 & 15 & $400 \times 1.5$ & $900^{4)}$ & 1.5 & $4200^{2)}$ & 1.3 & \\
\hline$T_{8}$ & 270 & 15 & $400 \times 1.5$ & $100 \times 8$ & 1.33 & $\sim 150000^{2)}$ & 1.6 & $\pi$ \\
\hline
\end{tabular}


The compressive rigidity of the support stiffeners of the girders $T_{5}$ to $T_{8}$ was increased by $50 \%$ and an additional transverse stiffener was installed (Table 2). The distance $z$ from the end of the girder to the additional stiffener (Fig. 7) was $2 h$ for girders $T_{5}, T_{7}, T_{8}$, and $h$ for the girder $T_{6}$. The compressive rigidity of the flanges of the girders $T_{7}$ and $T_{8}$ was also increased.

The test results are shown in Table 3 where also results obtained by Höglund and Frey have been included. Comparison of numerical results of the continuous analytical, FEM, Eurocode 3 formulas and test results is shown in Fig. 8.

Table 2. Geometrical characteristics of the additional stiffeners

\begin{tabular}{l|c|c|c}
\hline Girder No. & $\begin{array}{c}\text { Location of the } \\
\text { stiffener } z, \\
\mathrm{~m}\end{array}$ & $\begin{array}{c}\text { Stiffness of the } \\
\text { stiffener } \\
\alpha_{S}=\mathrm{A}_{S} / \mathrm{A}_{w}\end{array}$ & $\begin{array}{c}\text { Stiffener cross- } \\
\text { section, } \\
\text { mm }\end{array}$ \\
\hline$T_{5}$ & 1 & 0.48 & $80 \times 6$ \\
$T_{6}$ & 0.5 & 0.48 & $80 \times 6$ \\
$T_{7}$ & 0.8 & 0.6 & $60 \times 6$ \\
$T_{8}$ & 0.8 & 0.8 & $80 \times 6$
\end{tabular}

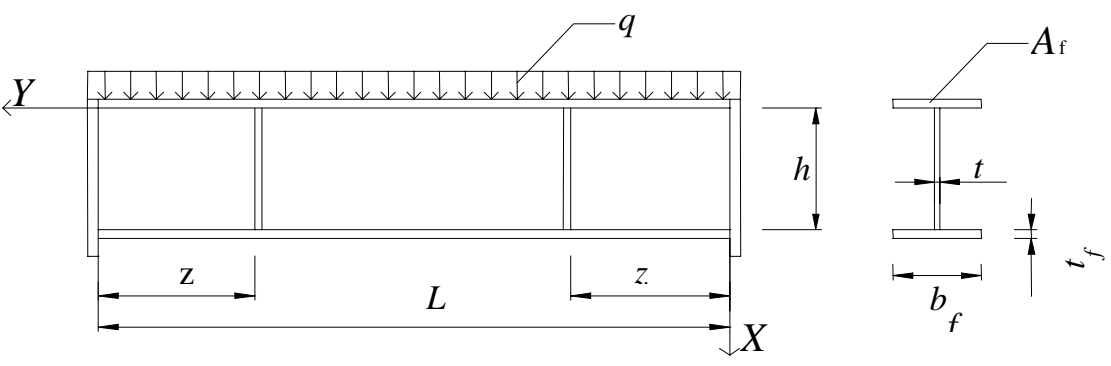

Fig. 7. Location of the additional stiffener.

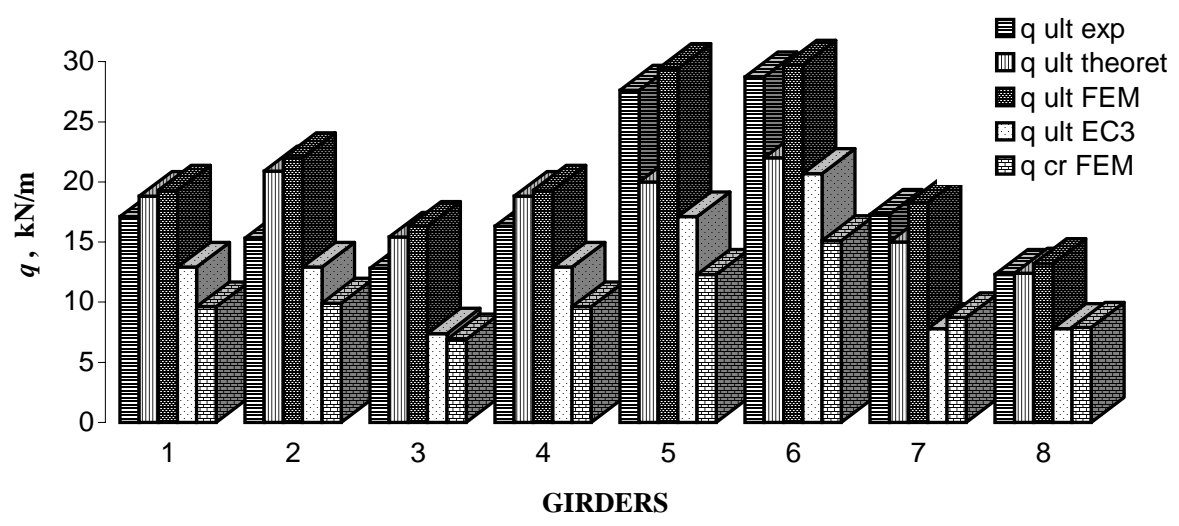

Fig. 8. Comparison of the ultimate load of the tested girders. 
Table 3. Comparison of the test results

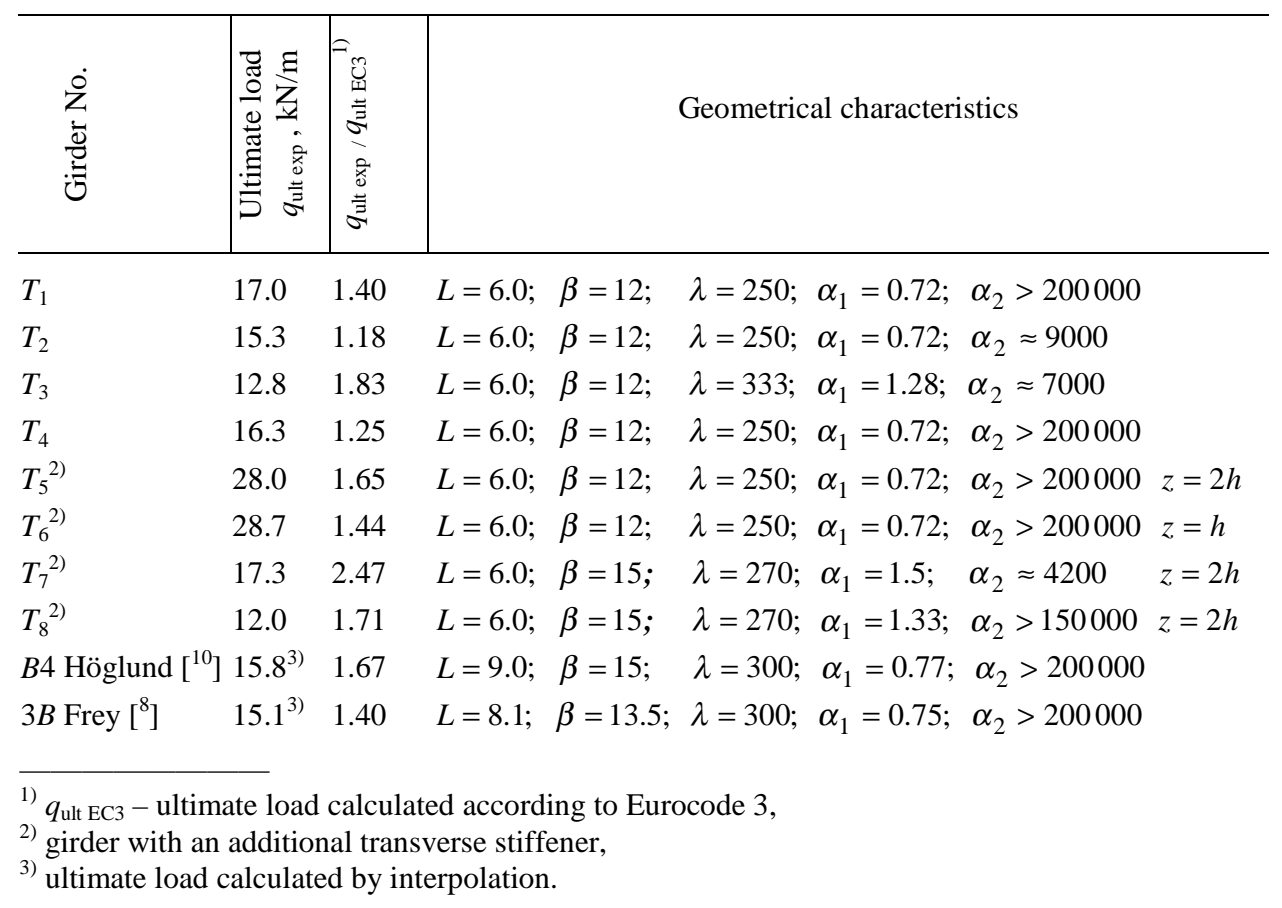

Installation of the additional stiffener resulted in an increase of the ultimate load capacity of the girders $T_{5}$ to $T_{8}$ approximately by $60 \%$, which was to be expected.

\section{CONCLUSIONS}

The buckling and ultimate loads of slender plate girders were investigated theoretically and experimentally. Eight girders of $6 \mathrm{~m}$ span were tested. The analysis included plate theory and use of the finite element method.

The results confirm that the ultimate load of a thin-walled girder without transverse stiffening ribs depends on the girder slenderness and on the compressive rigidity of the flanges. The buckling load depends on the torsional rigidity of the flanges, but this is not important for plate girders in which the span-to-depth ratio is relatively great.

In the post-critical situation, the largest deformations and stresses for girders of medium slenderness ratio ( $\beta=12$ to 16 ) appear in the supporting zone of the girder $(z=0$ to $z=2 h)$. For very slender girders $(\beta>16)$, the failure occurs in the middle of the girder. 
The ultimate load calculated using Eurocode 3 shear buckling resistance formulas $\left[{ }^{15}\right]$ is from 60 to $80 \%$ of the experimental ultimate load and from 50 to $70 \%$ of the load obtained using the plate theory and the finite element method.

\section{REFERENCES}

1. Škaloud, M. Failure mechanism of webs loaded in shear. Acta Techn. ČSAV, 1974, 5, 542-561.

2. Rockey, K. and Škaloud, M. Influence of flexural rigidity of flanges upon the load-carrying capacity and failure mechanism of webs in shear. Acta Techn. ČSAV, 1969, 3, 295-315.

3. Basler, K. Strength of plate girders in shear. J. Struct. Div. Proc. ASCE, 1961, 37, 151-180.

4. Williams, D. G. and Aalami, B. Thin Plate Design for In-Plane Loading. Granada, London, 1979.

5. Höglund, T. Shear buckling resistance of steel and aluminium plate girders. Thin-Walled Structures, 1997, 29, 13-30.

6. Höglund, T. Strength of Steel and Aluminium Plate Girders. Royal Institute of Technology, Department of Structural Engineering. Technical Report No. 4. Stockholm, 1995.

7. Benson, P. G. Shear Buckling and Overall Web Buckling of Welded Aluminium Girders. Ph.D Thesis. Royal Institute of Technology, Division of Steel Structures. Stockholm, 1992.

8. Frey, F. and Anslijn, R. Dimensionnement des poutres à lame pleine sans raidisseurs. CRIF. Construction Métallique, 1976, MT 114.

9. Höglund, T. Design of Thin Plate I Girders in Shear and Bending with Special Reference to Web Buckling. Royal Institute of Technology, Department of Building Statics and Structural Engineering. Stockholm, 1972.

10. Höglund, T. Livets verkningssät och bärformåga hos tunnväggig I-balk. Royal Institute of Technology, Department of Building Statics and Structural Engineering, Report No. 93, Stockholm, 1971.

11. Škaloud, M., Zörnerova, M., Kuhlmann, U., and Spiegelhalder, U. Prague and Stuttgart experimental research on web breathing. In Proc. International Conference EUROSTEEL. Prague, 1999. CD ROM.

12. Brož, P., Novak, M., and Škaloud, M. Experimental and theoretical investigation into the breathing of thin-walled steel girders. In Proc International Conference EUROSTEEL. Prague, 1999. CD ROM.

13. Timoshenko, S. P. and Woinosky-Krieger, S. Theory of Plates and Shells. McGraw-Hill, New York, 1989.

14. Varvak, P. M. and Rjabov, A. F. Handbook of the Theory of Elasticity. Budivelnik, Kiev, 1971 (in Russian).

15. COSMOS/M. Structural Research and Analysis Corp. Developers of COSMOS/M Applications. Los Angeles, CA, 1998.

16. ENV 1993-I-I. Eurocode 3: Design of Steel Structures. Part 1.1. General rules and rules for buildings.

\section{Jäikusribideta õhukeseseinaline tala ühtlasel koormusel}

\section{Priit Vilba ja Siim Idnurm}

Artiklis on kirjeldatud ühtlase hajukoormusega koormatud jäikusribideta õhukeseseinalise tala pingeid ja deformatsioone juhul, kui tala seina horisontaalsed servad on elastselt ühendatud vöödega ja vertikaalsed servad vabalt toetatud. On 
määratud tala seina stabiilsuse kadu tekitava ühtlaselt jaotatud koormuse, nihke-, painde- ja survepingete kriitilised väärtused. On uuritud tala seina pärastkriitilist olukorda eeldades, et pärastkriitilises olukorras on tala seinaosa vaadeldav servadel vabalt toetatud plaadina, mille koormus tasakaalustatakse külgservadel mõjuvate nihkejõudude poolt. Katsetulemusi on võrreldud pideva analüütilise meetodi, lõplike elementide meetodi ja Eurocode 3 valemite abil saadud arvutustulemustega. 